e-Journal Pendidikan Sosiologi Universitas Pendidikan Ganesha

Jurusan Sejarah, Sosiologi dan Perpustakaan (Volume 2, Nomor 2, Tahun 2020)

\title{
HUBUNGAN PENGINTEGRASIAN PENDIDIKAN MULTIKULTURAL PADA MATA PELAJARAN SOSIOLOGI DENGAN PERSEPSI DAN SIKAP KEMULTIKULTURAN SISWA (Studi Kasus: SMA Laboratorium Undiksha Singaraja, Bali)
}

\author{
Ni Wayan Pina Nangraini ${ }^{1}$, I Ketut Margi ${ }^{2}$, I Made Sarmita ${ }^{3}$ \\ Jurusan Serajah, Sosiologi dan Perpustakaan \\ Universitas Pendidikan Ganesha \\ Singajara, Indonesia \\ e-mail : \{ wayanpina.nangraini@gmail.com¹, ketut.margi@undiksha.ac.id², \\ made.sarmita@undiksha.ac.id\}
}

\begin{abstract}
Abstrak
Indonesia memiliki masyarakat yang sangat multikultur, sehingga peluang terjadinya konflik sangat besar. Salah satu upaya pemeritah untuk mengatasi masalah tersebut yaitu dengan memperbaiki kurikulum yang didalamnya terdapat pengintegrasian pendidikan multikultural.Tujuan penelitian ini yaitu: 1) Menganalisis hubungan pengintegrasian pendidikan multikultural dengan persepsi siswa, 2) Menganalisis hubungan pengintegrasian pendidikan multikultural dengan sikap kemultikulturan siswa dan 3) Menganalisis bentuk nyata pengintegrasian pendidikan multikultural di sekolah. Metode yang digunakan dalam penelitian ini yaitu metode mix dan jenis data yang digunakan data primer dan data skunder. Hasil penelitian menunjukan : 1) Terdapat hubungan positif dan signifikan antara pengintegrasian pendidikan multikultural pada mata pelajaran sosiologi dengan persepsi siswa, 2) Terdapat hubungan positif dan signifikan antara pengintegrasian pendidikan multikultural pada mata pelajaran sosiologi dengan sikap kemultikulturan siswa, 3) Bentuk nyata pengintegrasian pendidikan multikultural di sekolah dilakukandengan pengintegrasian pendidikan multikultural di kelas dan di luar kelas.
\end{abstract}

Kata kunci: Pendidikan Multikultural, Persepsi, Sikap Multikultural.

\begin{abstract}
Indonesia has a very multicultural society, so the chances of conflict are huge. The government has made an effort to overcome this problem by improving the curriculum in which there is integration of multicultural education. The objectives of this study are: 1) Describe the relationship of integrating multicultural education with students' perceptions, 2) Describe the relationship of integrating multicultural education with students' multicultural attitudes and 3) Describe the relationship of integrating multicultural education with students' perceptions, 2) tangible forms of integrating multicultural education in schools. The method used in this research is the mix method and the type of data used are primary data and secondary data. The results showed: 1) There was a positive and significant relationship between the integration of multicultural education in sociology subjects with students 'perceptions, 2) There was a positive and significant relationship between the integration of multicultural education in sociology subjects with students' multicultural attitude, 3) The real form of integrating multicultural education in schools is done by integrating multicultural education in the classroom and outside the classroom.
\end{abstract}

Keywords : Multicultural education, Perception, Multicultural ettitude 
e-Journal Pendidikan Sosiologi Universitas Pendidikan Ganesha

Jurusan Sejarah, Sosiologi dan Perpustakaan (Volume 2, Nomor 2, Tahun 2020)

\section{PENDAHULUAN}

Masyarakat Indonesia
merupakan masyarakat yang
multikultur sehingga pejuang pada
zaman kemerdekaan membuat
semboyan yakni Bhinneka Tunggal lka
yang mengandung arti "berbeda-beda
namun tetap satu”. Namun kemultikulturan yang dimiliki sering kali digunakan oleh oknum tertentu untuk kepentingan pribadi sehingga dapat mengakibatkan perpecahan atau konfik yang terjadi di masyarakat. Terdapat beberapa kasus masalah kemultikulturan masyarakat, seperti kasus pembakaran vihara di Tanjung Balai dan Sumatera Utara (Hadi dkk 2017). Sarmita (2014) juga melakukan penelitian yang berkaitan dengan konflik SARA yaitu kasus sampit antara etnis dayak dan etnis Jawa. Kharima (2017) juga meneliti tentang konflik yang disebabkan isu SARA, calon gubernur (cagub) yang berasal dari kelompok minoritas dan beliau terbentur pada kasus dugaan penistaan agama.

Konflik yang disebabkan oleh kemultikulturan masyarakat Indonesia bahkan tidak hanya terjadi di masyarakat luas, namun juga terjadi di masyarakat dalam lingkup sempit yaitu sekolah. Sekolah merupakan salah satu lembaga formal yang memiliki peranan penting dalam memberikan pemahaman multikultural terhadap siswa bahkan seluruh warga sekolahnya. Sangat disayangkan jika konflik SARA ini terjadi di sekolah yang merupakan tempat anak menuntut ilmu, salah satu kasusnya yaitu dikutip daari Tribunnew.com diakses pada tanggal 3 Mei 2018, terbitan 03 Mei 2017 Jakarta, yakni "siswa yang menolak ketua OSIS berbeda agama".

Pemerintah telah mengambil kebijakan dengan memperbaiki sistem pembelajaran seperti kurikulum yang menekankan

pengintegrasian

pendidikan multikulturan pada proses pembelajaran di kelas, sehingga guru dapat mengintegrasikan kurikulum tersebut dengan harapan siswa memiliki pemahaman multikultural lebih luas sehingga tidak terjadi konflik SARA, namun mengapa masih terdapat konflik SARA yang terjadi di sekolah, apakah guru belum melakukan pengintegrasi pendidikan multikulural di sekolah secara maksimal? Hal ini perlu diteliti lebih lanjut.

Pengintegrasian pendidikan multikultural tidak hanya di lakukan di kelas namun dapat juga dilakukan di luar kelas dengan kegiatan-kegiatan tertentu yang disiapkan sekolah untuk mendukung pengintegrasian tersebut. Peneliti melakukan penelitian terkait hubungan penggintegrasian pendidikan multikultural pada persepsi dan sikap siswa yaitu di SMA Laboratorium Undiksha Singaraja, Bali. Peneliti memilih sekolah tersebut sebagai tempat penelitian karena memiliki siswa yang paling multikultur dibandingkan dengan SMA lain di Singaraja, selain itu sesuai wawancara yang dilakukan, beberapa tahun sebelumnya terdapat siswa mengalami kesulitan beradaptasi karena merasa diri sebagai minoritas.Tujuan dari penelitian ini yaitu: 1) Mendiskripsikan persepsi siswa terhadap pengintegrasian pendidikan multikultural pada mata pelajaran sosiologi di SMA Laboratorium Undiksha Singaraja, Bali. 2) Mendiskripsikan hubungan pengintegrasian pendidikan multikultur terhadap sikap kemultkikulturan siswa di SMA Laboratorium Undiksha Singaraja, Bali. 3) Mendiskripsikan bentuk nyata dari pengintegrasian pendidikan multikultural di SMA 
Jurusan Sejarah, Sosiologi dan Perpustakaan (Volume 2, Nomor 2, Tahun 2020)

Laboratorium Undiksha Singaraja, Bali.

Pendidikan multikultural
merupakan pendidikan untuk
mengeksplorasi perbedaan sebagai
suatu anugerah yang datangnya dari
Tuhan (Rahim, 2012). Pendidikan
multikultural selalu memberikan
kesempatan kepada retiap
kebudayaan untuk berekspresi, dalam
pendidikan multikultural setiap
peradaban dan kebudayaan yang ada
berada dalam posisi yang sejajar atau
sama. Guru dalam mengintegrasikan
pendidikan multikultural dituntut untuk
dapat memberikan contoh sikap
multikultural tersebut, seperti saat
mengajar di kelas guru memperlakukan semua siswa secara adil dan setara. Terdapat 5 dimensi pendidikan multikultural menurut James Bank (2002) yaitu: 1) Dimensi integrai isi/materi, 2) Dimensi konstruk pengetahuan , 3) Dimensi pengurangan prasangka, 4) Dimensi pendidikan yang sama/adil, dan 5) Dimensi pemberdayaan budaya sekolah.

Selanjutnya, persepsi secara umum mengandung arti proses pemperoleh, menafsirkan, memilih serta pengaturan informasi yang didapatkan melalui alat indra. Persepsi mengandung suatu proses dalam diri seseorang untuk mengetahui dan mengevaluasi sejauh mana kita memahami orang lain (Sarlito W. Sarwono, 2014). Terdapat beberapa teori persepsi yaitu teori atribusi dan teori inferensi. Terdapat 3 dimensi persepsi yaitu: evaluasi, potensi, dan aktivitas.

Selanjutnya. sikap multikultural merupakan suatu pemikiran (kognitif) dan tindakan seseorang dalam memandang perbedaan dengan kesederajatan. Salah satu syarat agar sikap mutikultural efektif adalah bila kita mau menerima kenyataan bahwa manusia bukan makhluk sempurna, manusia adalah makhluk yang selalu menjadi, karena untuk menjadi, manusia membutuhkan sesamanya (Palpahan, 2017). Butet, dkk (2018) menjelaskan bahwa terdapat indikator sikap multikultural yaitu: 1) Apresiasi pluralis budaya, 2) Hakekat manusia dan HAM, dan 3) Pengembangan keterampilan sosial.

Pengintegrasian pendidikan multikultural memiliki hubungan dengan persepsi kemultikultural siswa. Semakin dilakukannya pengintegrasian pendidikan multikultural dengan baik, maka persepsi siswa akan kemultikulturan semakin meningkat. Persepsi mengandung suatu proses dalam diri seseorang untuk mengetahui dan mengevaluasi sejauh mana kita memahami orang lain, dengan dilakukan pengintegrasian pendidikan multikultural maka siswa akan meningkatkan rasa ingin tahunya terhadap kemultikulturan dan akan mempengaruhu persepsinya (Sarlito W. Sarwono, 2014).

Pengintegrasian pendidikan multikultural memiliki hubungan terhadap sikap kemultikulturan siswa. Semakin dilakukannya pengintegrasian pendidikan multikultural dengan baik, maka sikap kemultikulturan siswa akan meningkat. Pendidikan multikultural di sekolah juga harus dilakukan secara komprehensif, dengan didukung oleh kurikulum yang di dalamnya terdapat muatan pengembangan karakter serta pendidikan multikultural, dengan demikian akan memperbesar kemungkinan siswa memiliki persepsi kemultikulturan (Rosyada, 2014). Dari uraian diatan maka dapat dibuat hipotesis sebagai berikut:

\section{$H_{1}$ : Pengintegrasian pendididikan multikultural pada mata}


e-Journal Pendidikan Sosiologi Universitas Pendidikan Ganesha

Jurusan Sejarah, Sosiologi dan Perpustakaan (Volume 2, Nomor 2, Tahun 2020)

pelajaran sosiologi memiliki hubungan positif dan signifikan terhadap peresepsi kemultikulturan siswa.

\section{$H_{1}$ : Pengintegrasian pendididikan multikultural pada mata pelajaran sosiologi memiliki hubungan positif dan signifikan terhadap sikap kemultikulturan siswa.}

\section{METODE}

Penelitian ini menggunakan metode mix (kuantitatif dan kualitatif). Data yang digunakan dalam penelitian ini yaitu data primer dan data skunder. Data primer didapatkan melalui penyebaran kuesioner, hasil wawancara dengan guru mata pelajaran sosiologi dan beberapa siswa serta observasi di SMA Laboratorium Undiksha Singaraja Bali, sedangkan data sekuder berupa data siswa maupun sumber-sumber yang berkaitan dengan penelitian. Setelah data diperoleh maka peneliti melakukan analisis dan mendeskripsikan data tersebut. Penelitian ini adalah peneitian studi populasi dengan mengambil semua populasi sebagai sampel penelitian dengan jumlah 110 siswa.

Penelitian ini merupakan penelitian korelasional yang menganalisis mengenai hubungan pengintegrasian pendidikan multikultural pada mata pelajaran sosiologi dengan persepsi dan sikap kemultikulturan siswa serta bentuk nyata pegintegrasian pendidikan multikultural di SMA Laboratorium Undiksha Singaraja, Bali. Analisis yang digunakan dalam penelitian ini yaitu:

1. Uji Kualitas Instrumen,

a. Uji validitas dilakukan untuk mengetahui ketepatan alat yang digunakan untuk mengukur apa yang harus diukur. Item setiap pernyataan dinyatakan valid jika $t$ hitung $>t$ tabel dengan toleransi taraf kesalahan 5\%. Berdasarkan hasil uji validitas yang telah dilakukan dengan menggunakan aplikasi SPSS, terdapat 7 item yang nilai $t$ hitung $<\mathrm{t}$ tabel, maka item tersebut dinyatakan tidak valid dan dihapus. Item yang dihapus yaitu item nomor 2,12 , 13, 17, 25, 32, dan 35 karena tidak valid.

b. Uji reliabilitas Uji reliabilitas merupakan alat yang digunakan untuk mengukur kuesioner bertujuan untuk mengetahui kuesioner yang digunakan tersebut reliable atau tidak. Suatu kuesioner dikatakan reliabel jika responden dalam menjawab pernyaan atau pernyataan secara koniten dari waktu kewaktu. Varabel dikatakan reliable jika nilai dari Cronbach' Alpha> 0,60.

\section{Tabel 1}

Hasil Uji Reliabilitas

\begin{tabular}{cc}
\hline \multicolumn{2}{c}{ Reliability Statistics } \\
\hline Cronbach' & $\mathrm{N}$ of item \\
Alpha & \\
0,882 & 36 \\
\hline
\end{tabular}


e-Journal Pendidikan Sosiologi Universitas Pendidikan Ganesha

Jurusan Sejarah, Sosiologi dan Perpustakaan (Volume 2, Nomor 2, Tahun 2020) Sumber: Data Diolah Dari Hasil Kuesioner (disebarkan pada 18 Maret 2020)

2. Uji Persyaratan Analisis

a. Uji normalitas dilakukan untuk mengetahui apakah variabel bebas dan variabel terikat keduanya memiliki distribus i normal atau tidak, uji normalitas data dalam penelitian ini menggunakan uji
Kolmogorov-smirnov. Kriteria pengujian normalitas data menggunakan probabilitas berdistribusi normal jika nilai signifikan $\geq 0,05$ dan sebaliknya, data tidak berdistribusi normal jika nilai signifikan $\leq 0,05$.

Tabel 2

Uji Normalitas Data

\begin{tabular}{llc}
\hline \multicolumn{3}{c}{ One-Sample Kolmogorov-Smirnov Test } \\
\hline & $\mathrm{N}$ & Asymp. Sig. (2-tailed) \\
Pengintegrasian dan Sikap & 110 & 0,077 \\
Pengintegrasian dan Persepsi & 110 & 0,200 \\
\hline
\end{tabular}

sumber: Data Diolah Dari Hasil Kuesioner (disebarkan pada 18 Maret 2020)

b. Uji linearitas dilakukan untuk mengetahui apakah dua varabel mempunyai hubungan yang linier atau tidak. taraf signifikansi atau tidak dari linierity dengan menggunaka

kriteria pengujian yaitu jika signifikansi > 0,05 maka dikatakan non linier dan sebaliknya, jika signifikansi < 0,05 maka dikatakan linier (Ramzani, 2015).

Tabel 3

Uji Linearitas

\begin{tabular}{lc}
\hline \multicolumn{1}{c}{ Linearity } & Sig. \\
\hline Pengintegrasian dan Persepsi & 0,000 \\
Pengintegrasian dan Sikap & 0,000 \\
\hline
\end{tabular}

sumber: Data Diolah Dari Hasil Kuesioner (disebarkan pada 18 Maret 2020) 
e-Journal Pendidikan Sosiologi Universitas Pendidikan Ganesha

Jurusan Sejarah, Sosiologi dan Perpustakaan (Volume 2, Nomor 2, Tahun 2020)

3. Uji Hipotesis

a. Uji korelasi sederhana yaitu korelasi yang digunakan untuk mengetahui keeratan hubungan antara variabel independen dan variabel dependen Ramzani (2015).

b. Uji signifikan korelasi sederhana dilakukan bertujuan mengetahui apakah hasil perhitungan korelasi sederhana signifikan atau tidak signifikan. kriteria dari pengujian signifikan korelasi sederhana yaitu jika sig < 0,05 maka Ho ditolak dan jika sig > 0,05 maka Ho diterima.

4. Pengecekan Keabsahan Data

\section{HASIL DAN PEMBAHASAN}

Deskripsi data dilakukan untuk memberikan gambaran secara umum terkait penyebaran data yang telah dilakukan di lapangan. Sebelum peneliti menyebarkan instrumen ke tempat penelitian, kuesioner tersebut diujikan terlebih dahulu di salah satu SMA yang ada di Singaraja yaitu SMAN 4 Singaraja. Setelah kuesioner disebarkan, selanjutnya dilakukan beberapa uji yaitu uji validitas dan uji reliabilitas. Kuesioner tersebut terdiri dari 36 item, setelah diuji tedapat 7 item yang tidak. Penelitian ini dilakukan dengan menyebarkan kuesioner melalui google form di SMA Laboratorium Undiksha khususnya pada siswa jurusan IImu Sosial kelas X, XI, dan XII dengan jumlah populasi yaitu 110 siswa. Selain melakukan penyebaran kuesioner, peneliti juga melakukan wawancara dengan guru sosiologi di SMA Laboratorium Undiksha terkait pengintegrasian pendidikan multikulturan yang telah dilakukan
Ketika melakukan penelitian maka pengecekan keabsahan data adalah suatu keharusan. Pengecekan keaslian data pada penelitian kualitatif dilakukan dengan cara triangulasi data. Menurut Sugiyono (2013) menyatakan bahwa trangulasi data merupakan penggabungan beberapa teknik seperti teknik sumber data dan teknik pengumpulan suber data yang telah dilakukan. Sedangkan pengecekan keabsahan data pada penelitian kuantitatif dilakukan dengan uji validitas, uji reliabilitas, uji asumsi, dan uji hipotsis.

wawancara dilakukan dengan bantuan media berupa alat buku, dan pedoman. Data dalam penelitian ini terdiri dari tiga variabel yaitu pengintegrasian, persepsi dan sikap.

1. Pengintegrasian : variabel pengintegrasian memiliki tiga indikator yaitu Pengintegrasian pendidikan multukultural dalam kegiatan pendahuluan, Pengintegrasian pendidikan multukultural dalam kegiatan inti, dan Pengintegrasian pendidikan multukultural dalam kegiatan penutup.

2. Persepsi :variabel persepsi memiliki tiga indikator yaitu evaluasi, potensi, dan aktivitas.

3. Sikap : variabel sikap memiliki tiga indikator yaitu apresiasi pluralis budaya, hakekat manusia dan HAM, dan pengembangan keterampilan sosial. Hasil penyebaran uji statistic deskriptif dari penyebaran kuesioner dapat dilihat pada tabel 4 . 
e-Journal Pendidikan Sosiologi Universitas Pendidikan Ganesha

Jurusan Sejarah, Sosiologi dan Perpustakaan (Volume 2, Nomor 2, Tahun 2020)

Tabel 4

Hasil Uji Statistik Deskriptif Pengintegrasian, Persepsi, dan Sikap

\begin{tabular}{lccccc}
\hline & \multicolumn{5}{c}{ Descriptive Statistics } \\
& $\mathrm{N}$ & Minimum & Maximum & Mean & Std. Deviation \\
\hline Pengintegrasian & 110 & 43 & 60 & 52.79 & 4.348 \\
Persepsi & 110 & 24 & 40 & 35.56 & 3.460 \\
Sikap & 110 & 23 & 45 & 39.37 & 3.988 \\
\hline
\end{tabular}

Sumber: Data Diolah Dari Hasil Kuesioner (disebarkan pada 18 Maret 2020.

\subsubsection{Uji Hipotesis}

1. Uji Korelasi Sederhana

Korelasi sederhana yaitu korelasi yang digunakan untuk mengetahui keeratan hubungan antara variabel independen dan variabel dependen Ramzani (2015). Sebelum melakukan uji korelasi sederhana, terlebih dahuu dilakukan uji normalitas dan lineraritas.

Tabel

Hasil Uji Korelasi Pengintegrasian dan Persepsi

\begin{tabular}{llcr}
\hline & \multicolumn{2}{c}{ Correlations } \\
& & Integrasi & Persepsi \\
\hline \multirow{2}{*}{ Integrasi } & Pearson Correlation & 1 & $.648^{* *}$ \\
& Sig. (2-tailed) & 110 & .000 \\
& $N$ & $.648^{* *}$ & 110 \\
Persepsi & Pearson Correlation & .000 & 1 \\
& Sig. (2-tailed) & 110 & 110 \\
& $\mathrm{~N}$ & \\
$* *$
\end{tabular}

Sumber: Data Diolah Dari Hasil Kuesioner (disebarkan pada 18 Maret 2020)

Tabel 7

Hasil Uji Korelasi Sederhana Pegintegrasian dan Sikap

\begin{tabular}{llrr}
\hline \multicolumn{3}{c}{ Correlations } & \\
& & Integrasi & Sikap \\
\hline \multirow{2}{*}{ Integrasi } & Pearson Correlation & 1 & $.607^{* *}$ \\
& Sig. (2-tailed) & .000 \\
\multirow{4}{*}{ Sikap } & $\mathrm{N}$ & 110 & 110 \\
& Pearson Correlation & $.607^{* *}$ & 1 \\
& Sig. (2-tailed) & .000 & 110 \\
\multirow{2}{*}{ **. Correlation is significant at the 0.01 level (2-tailed). } \\
\hline Sumber: Data Diolah Dari Hasil Kuesioner (disebarkan pada 18 Maret 2020).
\end{tabular}


e-Journal Pendidikan Sosiologi Universitas Pendidikan Ganesha

Jurusan Sejarah, Sosiologi dan Perpustakaan (Volume 2, Nomor 2, Tahun 2020)

Jika dilihat pada tabel 6 dan tabel 7, hubungan antara variable bebas dan variable terikat yaitu kuat dan memiliki hubungan yang positif.

2. Uji Signifikan Korelasi Sederhana

Pengujian signifikansi dilakukan bertujuan mengetahui apakah hasil perhitungan korelasi sederhana signifikan atau tidak signifikan. Kriteria dari pengujian signifikan korelasi sederhana yaitu jika sig $<0,05$ maka Ho ditolak dan jika sig > 0,05 maka Ho diterima dengan pengujian menggunakan uji dua sisi (two tailed). Jika dilihat pada table 6 dan table 7,uji signifikan antara variable bebas dan variable terikat memiliki sig $<0,05$ yang berarti $\mathrm{H}_{1}$ diterima dan $\mathrm{H}_{0}$ ditolak.

\subsubsection{Bentuk Nyata Pengintegrasian} Pendidikan Multikultural di SMA Laboratorium Undiksha Singaraja, Bali.

Berdasarkan hasil wawancara yang dilakukan oleh peneliti epada guru sosiologi dan siswa SMA Laboratorium Undiksha terdapat beberapa cara dalam mengintegrasikan pendidikan multikultural di sekolah yaitu:

1. Pengintegrasian pendidikan multikulturaldi dalam kelas yang dilakukan dalam proses pembelajaran dengan membuaat RPP yang di dalamnya terdapat kegiatan pembuka, inti, dan penutup.

2. Pengintegrasian pendidikan multikultural di luar kelas yang dilakukan dengan menyediakan bimbingan konseling, ekstrakurikuler, ucapan selamat hari raya agama, dan lomba-lomba di sekolah yang dapat mempererat rasa kebersamaan siswa.

\section{PEMBAHASAN}

4.2.1Hubungan

Pengintegrasian

Pendidikan Multikulturap Pada

Mata Pelajaran Sosiologi di

SMA Laboratorium Undiksha dengan Persepsi

\section{Kemultikulturan Siswa}

Berdasarkan hasil pengujian hipotesis yang dapat dilihat pada tabel 4.5, dimana hasil uji korelasi sederhana yaitu 0,648 yang dikategorikan memiliki hubungan kuat yaitu berada diantara rentang 0,600-0,700. Nilai tersebut menunjukan bahwa terdapat hubungan positif antara pengintegrasian dengan persepsi siswa. Pada uji signifikan korelasi sederhana, hasil yang diperoleh dari integrasi dan persepsi yaitu dengan nilai sigfikan $0,000<0,05$, maka dapat dikatakan bahwa pengintegrasian pendidikan multikultural memiliki hubungan yang signifikan terhadap persepsi kemultikulturan siswa. Persepsi seseorang terhadap suatu hal tergantung kepada pengetahuan yang dimilikinya yang didapatkan dari lingkungannya, baik lingkungan keluarga, sekolah maupun masyarakat. Seperti konsep dasar teori atribusi, bahwa setiap orang mempersepsikan sifat sesuai situasi-situasi yang dihadapinya di lingkungan sekitar (Listyana dan Hartono, 2015). Seperti yang dijelaskan oleh Rosyada (2014) bahwa pendidikan multikultural di sekolah harus dilakukan secara komprehensif, dengan didukung oleh kurikulum yang di dalamnya terdapat muatan pengembangan karakter serta pendidikan multikultural, sehingga pendidikan multikulturan tersebut dapat terealisasi sesuai harapan. Seperti penelitian yang sudah dilakukan oleh 
e-Journal Pendidikan Sosiologi Universitas Pendidikan Ganesha

Jurusan Sejarah, Sosiologi dan Perpustakaan (Volume 2, Nomor 2, Tahun 2020)

Septia Ningsih (2017), hasil penelitiannya menunjukkan persentase peran guru dan penanaman nilai-nilai multikultural sebanyak $55 \%$ menyatakan kategori cukup berperan. Hal tersebut dapat terjadi karena ditunjang oleh kurikulum dan proses pembelajaran yang dilakukan dengan baik.

\subsubsection{Hubungan Pengintegrasian Pendidikan Multikulturap Pada Mata Pelajaran Sosiologi di SMA Laboratorium Undiksha dengan Sikap Kemultikulturan Siswa}

Berdasarkan hasil pengujian hipotesis yang dapat dilihat pada tabel 4.6, dimana hasil uji korelasi sederhana yaitu 0,607 yang dikategorikan memiliki hubungan kuat yaitu berada diantara rentang 0,600-0,700. Nilai tersebut menunjukan bahwa terdapat hubungan positif antara pengintegrasian dengan sikap siswa. Pada uji signifikan korelasi sederhana, hasil yang diperoleh dari integrasi dan sikap yaitu dengan nilai sigfikan $0,000<0,05$, maka dapat dikatakan bahwa pengintegrasian pendidikan multikultural memiliki hubungan yang signifikan terhadap sikap kemultikulturan siswa. Jika dilihat dari hasil tersebut, dapat disimpulkan bahwa sekolah terutama guru telah melakukan pengintegrasian pendidikan multikulturan pada saat proses pembelajaran sesuai dengan kurikulum serta perencanaan pembelajaran. Seperti pernyataan yang disampaikan oleh Afifah (2017), bahwa paa dasrnya unsur utama dalam pengintegrasin pendidikan multikultural adalah penempatan posisi siswa sebagai subjek yang bersifat sejajar. Sikap seseorang tentu saja dipengaruhi oleh seberapa luas pengetahuan yang ia miliki. Palpahan (2017) menyatakan bahwa salah satu syarat agar sikap mutikultural efektif adalah bila kita mau menerima kenyataan bahwa manusia bukan makhluk sempurna, manusia adalah makhluk yang selalu menjadi, karena untuk menjadi, manusia membutuhkan sesamanya, jika siswa memiliki wawasan multikultural yang memadai maka siswa akan memahami hal tersebut.

\subsubsection{Bentuk Nyata Pengintegrasian} Pendidikan Multikultural di SMA Laboratorium Undiksha Singaraja, Bali.

Bentuk nyata pengintegrasian pendidikan multikultural di SMA Laboratorium Undiksha Singaraja, Bali dilakukan dengn 2 cara yaitu pengintegrasian di dalam kels dan pengintegrsin di luar kelas.

1. Pengintegrasian Pendidikan Multikultural di kelas.

Abad ke 21 seorang guru harus memiliki 4 (empat) jenis keterampilan, salah satunya adalah keterampilan pedagogis. Keterampilan ini diimplementasikan dalam berbagai macam cara, salah satunya adalah penyusunan RPP sebagai pedoman pelaksanaan pembelajaran di SMA Laboratorium Undiksha Sinaraja, Bali. Terdapat tiga langkah dalam RPP yaitu: 1) Kegiatn Pendahuluan diawali dengan berdoa sesuai agama masing-masing sebagai wujud bersyukur dan saling menghargai, selanjutnya mengecek kehadiran siswa dengan merangsang rasa perduli siswa terdahap teman-teman yang ada di kelas, setelah itu dilanjukan dengan membentuk kelompok belajar, sesuai dengan wawancara yang dilakukan dengan guru sosiologi pembagian kelompok dilakukan sesuai keinginan siswa. Pembentukan kelompok akan lebih baik jika dilakukan secara acak antara laki-laki dan perempuan, antara agama, antara etnis, maupun budaya siswa. Hal ini sejalan dengan yang dikatakan oleh Mahmudi (2006) 
e-Journal Pendidikan Sosiologi Universitas Pendidikan Ganesha

Jurusan Sejarah, Sosiologi dan Perpustakaan (Volume 2, Nomor 2, Tahun 2020)

bahwa pada prinsipnya untuk membentuk kelompok di kelas yang siswanya heterogen harus dilakukan dengan membagi siswa yang berbeda sikap pendiam dengan siswa yang mudah berkomunikasi, siswa yang memiliki motivasi tinggi dengan siswa rendah diri, selain itu juga memertimbangkan gender, dan etnis. Pernyataan tersebut didukung oleh Hanum (2009) bahwa pembentukan setiap kelompok di kelas terdiri siswa yang berbeda latar belakang sehingga mereka belajar kekurangan dan kelebihan yang dimiliki masing-masing. 2) Kegiatan Inti diawali dengan literasi yang dilakukan oleh siswa agar siswa paham dengan materi yang akan disampaikan, setelah itu guru akan menjelaskan matei yang diajarkan dengan menyelipan pendidikan multikultural, selanjutnya akan dilakukan kegiatan kerja sama siswa dalam menyelesaikan masalah dari pemikiran dan pendapat yang berbeda-beda yang mengajarkan siswa untuk saling menghargai dan mencari solusinya, setelah itu dilanjutkan dengan presentasi yang membangun sikap tanggung jawab siswa. Penjelasan tersebut sejalan dengan pendapat yang dikemukakan oleh Harsanto (2007) bahwa pembelajaran dengan pembentukan kelompok dapat menumbuhkan kerja sama, percaya diri, dan kekompakan dari siswa.Seperti penelitian olehFaiqoh (2016) bahwa untuk meningkatkan rasa saling menghargai, dipelukan metode pembelajaran yang tepat salah satunya pembentukan kelompok saat proses pembelajaran. 3) Kegiatan Penutupan diawali dengan guru memberi penilaian kepada siswa, memberi tugas kepada siswa dan pembelajaran diakhiri dengan doa bersama sesuai agama masing-masing.

2. Pengintegrasian Pendidikan Multikultural di luar kelas dilakukan dengan beberapa cara: 1) menyediakan bimbingan konseling (BK) yang dapat memberikan bimbingan keada siswa yang mengalami kesulitan dalam beradaptasi dengan lingkungan yang mutikultural. Penjelasan di atas sejalan dengan penelitian yang dilakukan oleh Pandansari (2007) bahwa melalui bimbingan konseling yang diberikan kepada siswa, terdapat perubahan pada diri siswa yaitu mulai berani mengemukakan pendapat/ide, mulai bersikap terbuka terhadap lingkungannya, semakin akrab dengan siswa lain, dan memperoleh keterampilan sosial melalui pembinaan. 2) ekstrakurikuler yang disediakan dengan memberikan kesempatan kepada semua siswa untuk ikut serta dengan tujuan siswa dapat mengenal lebih banyak teman dan mendapatan pengalaman baru serta dapat menumbuhkan kebersamaan dalam diri siswa. Sejalan dengan yang jelaskan oleh Gerungan (2004) bahwa situasi kebersamaan merupakan sekumulan orang yang awalnya belum saling mengenal dan bertemu pada satu kegiatan yang menuntut mereka untuk terus berinteraksi dan memiliki rasa untuk saling mendukung. 3) ucapan selamat hari raya agama dilakukan oleh sekolah dengan membuat ucapan selata di media sosial salah satunya facebook, selain itu cucapat selamat hari raya wajib dilakukan guru dan mengajak semua siswa untuk melakukan hal tersebut sehingga terbiasa menghargai teman-teman mereka saat merayakan hari raya agama. 4) lomba-lomba sekolah dilakuakan 
e-Journal Pendidikan Sosiologi Universitas Pendidikan Ganesha

Jurusan Sejarah, Sosiologi dan Perpustakaan (Volume 2, Nomor 2, Tahun 2020)

pada hari-hari tertentu, seperti ulang tahun sekolah dengan mengadakan acara jalan santai, lomba akademik dan non akademik, hari raya saraswati dengan membuat kegiatan lomba membuat pajekan yang melibatkan semua siswa, dan hari bahasa yang membuat lomba-lomba. Lomba dibuat dengan tujuan memperkuat rasa kebersamaan dan saling mendukung siswa untuk mengikuti sekaligus memenangkan lomba-lomba antar kelas tersebut.Sejalan dengan yang jelaskan oleh Gerungan (2004) bahwa situasi kebersamaan merupakan sekumulan orang yang awalnya belum saling mengenal dan bertemu pada satu kegiatan yang menuntut mereka untuk terus berinteraksi dan memiliki rasa untuk saling mendukung.

\section{SIMPULAN DAN SARAN \\ Simpulan}

Berdasarkan hasil penelitian dan pembahasan di atas, maka dapat dibuat simpulan dalam penelitian ini. Adapun simpulan dalam penelitian ini yaitu: Terdapat hubungan positif dan signifikan antara pengintegrasian pendidikan multikultural pada mata pelajaran sosiologi dengan persepsi kemultikulturan siswa. Terdapat hubungan positif dan signifikan antara pengintegrasian pendidikan multikultural pada mata pelajaran sosiologi dengan sikap kemultikulturan siswa. Bentuk nyata pengintegrasian pendidikan multikultural dilakukan dengan 2 cara yaitu pengintegrasian di kelas dengan membuat Rencana Pelaksanaan Pembelajaran (Kegiatan Pendahuluan, Inti, dan Penutupan). Pengintegrasin pendidikan multikultural di luar kelas dengan cara menyediakan bimbingan konseling (BK), ekstrakurikuler, ucapan selamat hari raya agama, dan lomba-lomba sekolah.

\section{Saran}

Berdarkan hasil penelitian terdapat beberapa saran yang dapat peneliti berikan yaitu bagi sekolah dirapkan dapat lebih meningkatkan pengintegrasian pendidikan multikultural melalui kegiatan-kegitatan yang lebih mengkhusus dan melibatkan semua siswa agar dapat meningkatkan pemahaman siswa tentang pendidikan multikultural, selain itu untuk penggunaan baju adat bali sebaiknya bagi yang berasal dari daerah selain Bali diberi kesempatan untuk menggunakan baju adat meraka, jadi selain melestarikan adat bali sekaligus dapat melestarikan budaya seluruh daerah yang ada di Indonesia. budaya dan tradisi yang dimiliki oleh masyarakat.

\section{UCAPAN TERIMA KASIH}

Terima kasih saya ucapkan kepada pembimbing 1 dan pembimbing 2 yang telah memberikan bimbingan dan motivasi kepada saya sehingga artikel ini dapat saya kerjakan dengan baik, begitu pula saya ucapkan terima kasih kepada seluruh rekan-rekan yang telah membantu dan mendukung saya.

\section{DAFTAR PUSTAKA}

Afifah, Nurul. 2017. "Implementasi Pembelajaran Berbasis Multikultur dan Budaya di SD/Ml". Jurnal Pendidikan Dasar. Volume 1 Nomor 01 (hal.24-44).

Bank, A James. 2002. "An Introduction to Multicultural Education". Boston: A Pearson Education Company.

Butet, S., Djoko, Saryono., \& Taufik Dermawan. 2018. "Konstruksi Pengetahuan Multikultural dalam Buku Tematik Terpadu untuk SD/MI kelas IV". Jurnal Pendidikan. Volume 3, Nomor 3 (hal. 334-339). 
e-Journal Pendidikan Sosiologi Universitas Pendidikan Ganesha

Jurusan Sejarah, Sosiologi dan Perpustakaan (Volume 2, Nomor 2, Tahun 2020)

Faiqoh, A. 2016. "Implementasi Pendidikan Multikultural Pada Mata Pelajaran PPKn Tema Ekosistem Kelas VA di MI Negeri Sumurrejo Kecamatan Gerungan, W.A. 2004. "Psikologi Sosial". Bandung : PT. Rafika Aditama

Hadi, D. W., dkk. 2017. "Analisis Sikap Toleransi di Indonesia dan Faktor-Faktornya". Diterbitkan oleh PDSPK Kemdikbud RI.

Hanum, Farida. 2009."Pendidikan Multikutural sebagai Sarana Pembangun Karakter Bangsa (dalam Persektif Sosiologi Pendidikan). Seminar Regional Universitas Negeri Yogjakarta.

Kharisma, T. 2017. "Konflik SARA pada Pilkada DKI Jakarta di Grup Whatsapp dengan Anggota Multikultural. Jurnal Penelitian Komunikasi. Vol. 20 No. 2 (hal.107-120).

Listya, R., Hartono Yudi. 2015. "Persepsi dan Sikap Masyarakat Terhadap Penanggalan Jawa dalam Penentuan Waktu Pernikahan (Studi Kasus Desa Jonggrang Kecamatan Barat Kabupaten Magetan Tahun 2013). Jurnal Agastya. Vol 5 No 1 (hal.118-137).

Mahmudi, Ali. 2006."Pembelajaran Kolaboratif". Jurnal Seminar Nasional MIPA.

Ningsih, S. 2018. "Peran Guru dalam Menanamkan Nilai-Nilai Multikultural Peserta Didik SMA N 1 SidomulyoTahun Pelajaran 2017/2018". Sripsi Universitas Lampung tidak diterbitkan.

Pakpahan, D. R. 2017. "Pengaruh Pengetahuan dan Sikap Terhadap Perilaku Masyarakat pada Bank Syariah di Wilayah Kelurahan Sei Sikambing D". jurnal diterbitkan oleh At-Tawassuth. Volume 3, Nomor.3 (hal. $345-367$ ).
Gunungpati Kota Semarang". Skripsi Universitas Islam Negeri Walisongo tidak diterbitkan.

Pandansari, R.2007. "Efektivitas Bimbingan Kelompok dalam Upaya Mengembangkan Sikap Prososial pada Siswa Kelas $X$ SMA Teuku Umar Semarang Tahun Ajaran 2006/2007". Skripsi UNNES tidak diterbitkan

Harsanto, R. 2007."Pengelolaan Kelas yang Dinamis". Yoyakarta: Konisius.

Rahim, Rahmawaty. 2012. "Signifikansi Pendidikan Multikultural Terhadap Kelompok Minoritas". Jurnal Analisis. Volume 12, Nomor 1 (hal.161-182).

Rosyada, Dede.2014." Pendidikan Multikultural IndonesiaSebuah Pandangan Konsepsional". Jurnal Sosio Didaktika. Vol. 1, No (hal.2-12).

Ramzani, E. 2015. "Hubungan Pengalaman Praktik Kerja Industri dengan Minat Siswa dalam Berwirausaha di SMK Muhammadiyah Prambanan. Skripsi Universitas Yogyakarta tidak diterbitkan.

Sarmita, I Made. Potensi Konflik di Daerah Tujuan Transmigrasi (Kasus Sampit dan Mesuji). Jurnal Media Komunikasi Geografi. Vol. 15 Nomor 1 (hal.45-59).

Sarwono, Sarlito W. 2014. "Pengantar Psikologi Umum". Jakarta: Rajawaki Press.

Sugiyono. 2013. "Metode Penelitian Kuantitatif Kualitatif dan R\&D". Bandung: Alfa

Haryadi, M. 2017. "Benih-benih Intoleransi di Sekolah: Siswa Tolak Ketua OSIS yang Beda Agama". Tribunnews.com. http://www.tribunnews.com/nas 
e-Journal Pendidikan Sosiologi Universitas Pendidikan Ganesha

Jurusan Sejarah, Sosiologi dan Perpustakaan (Volume 2, Nomor 2, Tahun 2020) ional/2017/05/03/benih-benih-i

ntoleransi-di-sekolah

siswa-tolak-ketua-osis-yang-be

da-agama. (diakses tanggal 5

Mei 2019). 